\title{
Joining Car Body Steel Sheets Using the Clinching Method
}

Emil Spišák(SK) emil.spisak@tuke.sk

Luboš Kaščák(SK) lubos.kascak@tuke.sk

\section{BIOGRAPHICAL NOTES}

Emil Spišák, prof. CSc. (born in 1955) is professor of Department of Technologies and Materials, Faculty of Mechanical Engineering, Technical University of Košice. He is head of the Department of Technologies and Materials and Vice-Rector for Development and Construction of the University. He served as Vice-Dean for 4 years and Vice-Rector for 8 years. He works in the area of evaluating of material properties, material failures, analysis and quantification of production factors influence in production of thin steel sheet stamping parts, modelling and simulation of technological processes, mainly forming processes. He is national secretary and a member of International DeepDrawing Research Group. He is author of 5 monographs and more than 200 publications in journals and conference proceedings at Slovakia and abroad. His published works were cited 115 times. He has been worked on 60 grant projects, research tasks and 47 projects solved for industry.

Luboš Kaščák, Ing. PhD. (born in 1974) is an assistant professor at the Department of Technology and materials. He received scientific degree PhD. in 2004 in the field of properties evaluation of joined deep drawn sheets. He is an author of more than 70 publications in journals and conference proceeding in Slovakia and abroad. He has worked on several grant projects and research tasks.

\section{KEY WORDS}

Clinching, Car Body Sheets, Evaluation of Properties

\section{ABSTRACT}

The paper deals with joining steel sheets for automotive industry using the clinching method. This method is a relatively new technique in joining car body sheets and it is beginning to find its place in the automotive industry as an alternative to resistance spot welding, especially in joining materials of different qualities or materials with different surface treatment. Combination of three hot-dip galvanized steel sheets: microalloyed steel sheet H220PD with the thickness of 0,8 mm, TRIP steel $40 / 70+Z 100 \mathrm{MBO}$ with the thickness of $0,77 \mathrm{~mm}$ and drawing grade sheet $\mathrm{DX} 51 \mathrm{D}+\mathrm{Z}$ with the thickness of $0,9 \mathrm{~mm}$ were used for the experiments. The tensile test and metalographical analysis were used for the evaluation of the clinched joints properties. We observed the influence of the sheets' position during clinching (taking into consideration the materials and the active parts of the tool - punch and die) on the carrying capacity of the joint. 


\section{INTRODUCTION}

Contemporary automotive industry is a challenging business. It is required not only to respond to environmental concerns such as greenhouse gases and fuel economy, but also to meet customer expectations [1]. The car body consists of a combination of several materials, which is a result of material and energy saving trends applied in car body production. The production of vehicles with lower weight and consequently also lower fuel consumption is responding to ecological demands of reduction of emissions into the environment. There is a need to join different materials - materials of various thicknesses, qualities, surface treatments [2]. Such practice in car body production opens new possibilities for designers in optimal utilization of properties of various materials, which can be combined into one construction. For example, the cheapest materials can be situated in the common parts of pressing in car body, good-quality sheets can be situated in the critical places of deformation and high-strength sheets can be used in the exposed places due to demands of construction - deformation zones [3]. These demands lead to research in the area of material joining with the emphasis mainly on carrying capacity of joints, quality of joints and corrosion resistance.

It is not always possible to achieve the required quality of joints in automotive industry when classical methods of joining like resistance spot welding and laser brazing are used. There is a need to conduct research into alternative methods of material joining. One of the alternative joining methods used in automotive industry is clinching [4].

Clinching is a joining method in which sheet metal parts are deformed locally without the use of any additional elements [5]. It is mechanical press joining by local forming, which can be widely applied in manufacture of thin-walled structures, especially in the automotive industry. It consists in clamping together several sheet metals by an impact extrusion between a punch and a die [6]. Another clinching method used in the automotive field is self-piercing riveting with the semi-tubular rivets [7].

The paper evaluates joints made by clinching the following materials: microalloyed steel HSLA H220PD, TRIP steel 40/70+Z100MBO and drawing grade steel DX51D $+Z$.
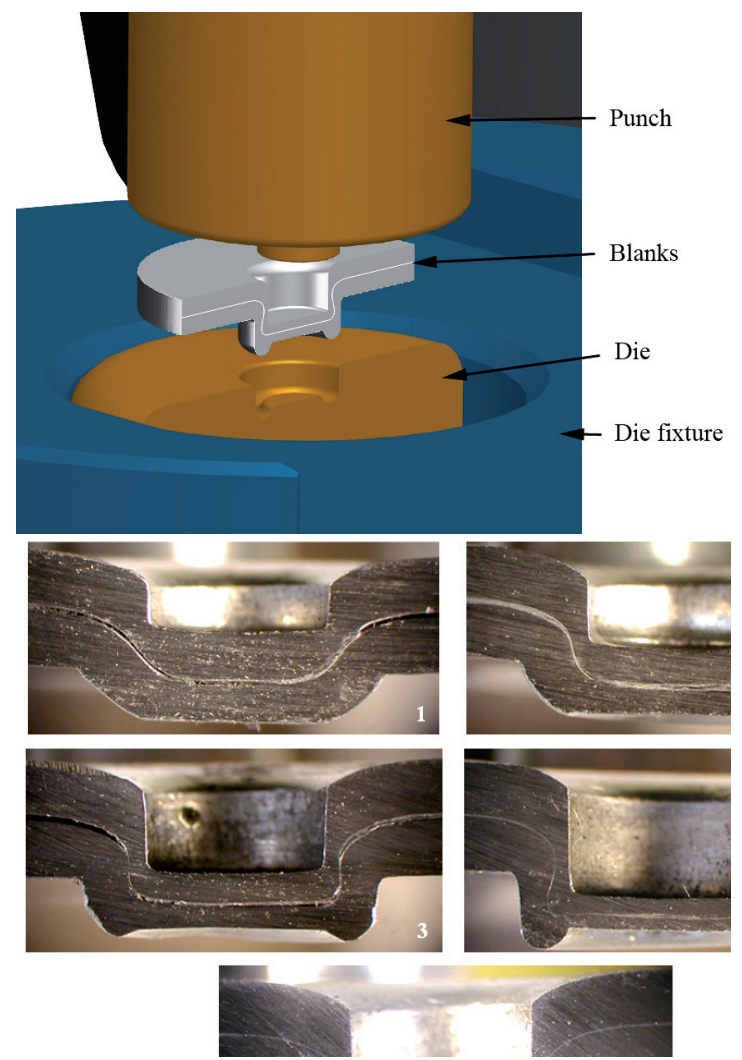

Fig. 1Clinching tool and the mechanism of joint creation [10]

\section{Clinching Process}

The clinching process is a combination of drawing and forming that locks together sheets metal layers [8]. The blanks are plastically deformed and the shape of the tools remains theoretically unchanged during the clinching processes. The punch is movable, whereas the fixture and the die are fixed during the process (Fig. 1). The punch force needed for the joining process depends on the thickness and the strength of the materials to be joined, the size of the tools and friction coefficient usually varies from 10 to $100 \mathrm{kN}$ [9].

The technology has many advantages, such as no pre-drilled hole requirement, capability to join a wide range of similar or dissimilar materials and combinations of materials (Fig. 2 and Fig. 3), no fume emissions etc. However, the process is limited by the inability to change process parameters such as rivet size or die configuration "on the fly" between successive joint positions on a vehicle structure. This leads to potential increasing costs and limits the application of the technology [1]. 
This method should be used as an alternative to resistance spot welding, especially in joining of combination of materials. Comparisons of carrying capacities between joints made by clinching and resistance spot welding were published mainly in [10-12].

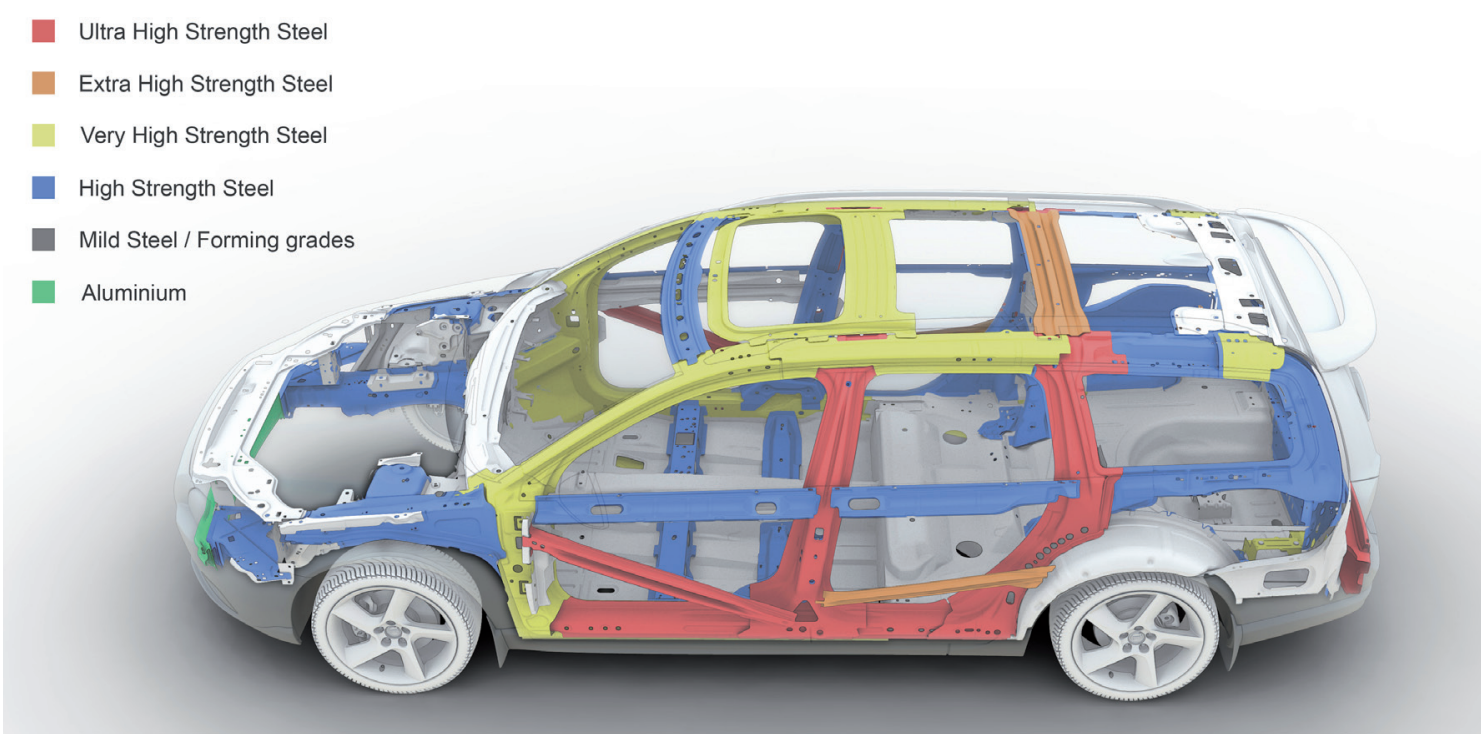

Fig. 2 Combination of materials used in car body of Volvo V70
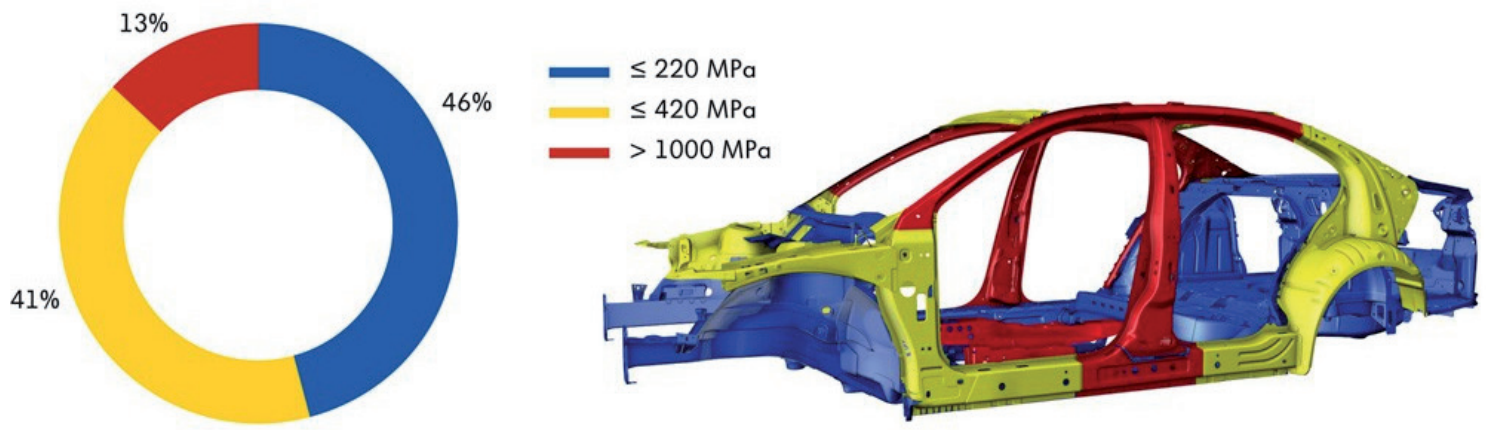

Fig. 3 Range of materials used in car body production (VW Jetta)

\section{Materials and Experiments}

The following steel sheets were used for experimets: microalloyed steel HSLA H220PD with the thickness of $0,8 \mathrm{~mm}$, TRIP $40 / 70+Z 100 \mathrm{MBO}$ with the thickness of $0,77 \mathrm{~mm}$ and DX51D $+Z$ with the thickness of $0,9 \mathrm{~mm}$.

Their basic mechanical properties and chemical composition are shown in Tabs. 1 and 2. Properties of DX51D steel were specified by producer.

According to the orientation of punch and die to the position of upper and lower joined material, following combinations of steel sheets for press joining were used:
Samples A: H22OPD $\left(a_{0}=0,80 \mathrm{~mm}\right)$ and TRIP $\left(a_{0}\right.$ $=0,77 \mathrm{~mm})^{*}$

- Samples B: TRIP $\left(a_{0}=0,7 \mathrm{~mm}\right)$ and H220PD $\left(a_{0}=\right.$ $0,80 \mathrm{~mm})^{*}$

Samples C: H22OPD $\left(a_{0}=0,80 \mathrm{~mm}\right)$ and H22OPD $\left(a_{0}=0,80 \mathrm{~mm}\right)$

Samples D: TRIP $\left(a_{0}=0,77 \mathrm{~mm}\right)$ and DX51D $\left(a_{0}=\right.$ $0,90 \mathrm{~mm})^{*}$

Samples E: DX51D $\left(a_{0}=0,90 \mathrm{~mm}\right)$ and TRIP $\left(a_{0}=\right.$ $0,77 \mathrm{~mm})^{*}$

( ${ }^{*}$ sheet on the die side of press joining tool)

The samples of $40 \times 90 \mathrm{~mm}$ dimensions with the length of lapping $30 \mathrm{~mm}$ according to STN 05 
1122 standard were used for the experiments. Six samples were prepared for every combination of sheets. Beacuse of the used joining method, it was not necessary to clean the surfaces of samples before clinching.

\begin{tabular}{|c|c|c|c|c|}
\hline Material & $\begin{array}{c}\text { Rpo,2 } \\
\text { [MPa] }\end{array}$ & $\begin{array}{c}\mathbf{R m} \\
\text { [MPa] }\end{array}$ & \multicolumn{1}{|c}{$\begin{array}{c}\mathbf{A 8 0} \\
\text { [\%] }\end{array}$} & $\mathbf{n}_{\mathbf{9 0}}$ \\
\hline H220PD & 238 & 382 & 36 & 0,228 \\
\hline TRIP 40/70 & 450 & 766 & 26 & 0,278 \\
\hline DX51D & & $450^{*}$ & $23^{*}$ & \\
\hline
\end{tabular}

Tab. 1 Basic mechanical properties of used steels (*specified by producer)
Clinching was performed on the tension machine ZD 40 made by Werkotoffrufmaschinen Leipzig Company with the loading range of $40 \mathrm{kN}$. The force needed for joining was $30 \mathrm{kN}$. The force for blankholder was $8 \mathrm{kN}$.

The carrying capacities of joints made with clinching were evaluated according to standard STN 05 1122 - Tensile test of spot welded joints. This test was used for measuring the maximum carrying capacities Fmax of pressed joints. The test was carried out on the testing machine for determination of strength of metals TIRAtest 2300 made by VEB TIW Rauenstein with the loading speed of $8 \mathrm{~mm} /$ min. The metallographical analysis was used for the evaluation of pressed joints quality.

Material

\begin{tabular}{|c|c|c|c|c|c|c|c|c|c|c|}
\hline & $\mathbf{C}$ & $\mathbf{M n}$ & $\mathbf{S i}$ & $\mathbf{P}$ & $\mathbf{S}$ & $\mathbf{A l}$ & $\mathbf{C u}$ & $\mathbf{N i}$ & $\mathbf{C r}$ & $\mathbf{T i}$ \\
\hline H220PD & 0,004 & 0,415 & 0,100 & 0,042 & 0,004 & 0,035 & 0,011 & 0,017 & 0,310 & 0,037 \\
\hline TRIP 40/70 & 0,204 & 1,683 & 0,198 & 0,018 & 0,003 & 1,731 & 0,028 & 0,018 & 0,055 & 0,009 \\
\hline DX51D & $0,15^{*}$ & & & $0,040^{*}$ & $0,040^{*}$ & & & & & \\
\hline & $\mathbf{V}$ & $\mathbf{N b}$ & $\mathbf{M o}$ & $\mathbf{Z r}$ & & & & & & \\
\hline H220PD & 0,002 & 0,026 & 0,005 & 0,001 & & & & & & \\
\hline TRIP 40/70 & 0,004 & 0,004 & 0,008 & 0,007 & & & & & & \\
\hline
\end{tabular}

Tab. 2 Chemical composition of used steel sheets ( ${ }^{*}$ specified by producer)

\begin{tabular}{|c|c|c|c|c|c|}
\hline Number of sample & \multicolumn{5}{|c|}{ Carrying capacity Fmax [N] } \\
\hline $\mathbf{1}$ & Samples A & Samples B* & Samples C & Samples D* & Samples E \\
\hline $\mathbf{2}$ & 939 & -- & 980 & -- & 1087 \\
\hline $\mathbf{3}$ & 985 & -- & 1008 & -- & 1584 \\
\hline $\mathbf{4}$ & 1016 & -- & 956 & -- & 1334 \\
\hline $\mathbf{5}$ & 1080 & -- & 924 & -- & 1834 \\
\hline $\mathbf{6}$ & 1093 & -- & 973 & -- & 1973 \\
\hline
\end{tabular}

Tab. 3 Measured values of carrying capacities of the clinched samples ( ${ }^{*}$ joints were not made)

\section{Analysis of Results}

The measured values of carrying capacities of clinched joints after tensile test are shown in Tab. 3. The carrying capacities of samples B and samples D were not measured, because clinched joints were not made. The upper sheets of both samples (TRIP 40/70 steel) were cut off in the place of the joint and then pressed to the lower sheet (Fig. 4 and Fig. 5).

No cracks were observed on the lower part of sheet on the die side of samples B and D.

The average value of carrying capacities of samples A was $1008 \mathrm{~N}$. The cracks in the TRIP steel of the die side were observed (Fig. 6), which could possibly have a negative effect, especially during dynamic load. The cracks can even decrease the joints' corrosion resistance. The values of carrying capacity of samples A are similar to the values measured in clinched joints of the common drawing grade steel sheets as was published in [2]. 


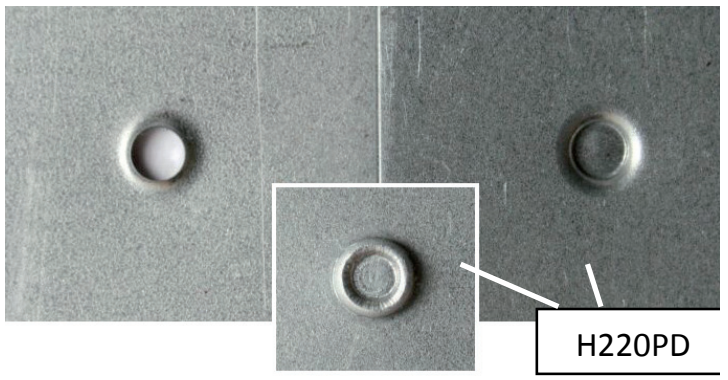

Fig. 4 Sample B without creating a clinched joint

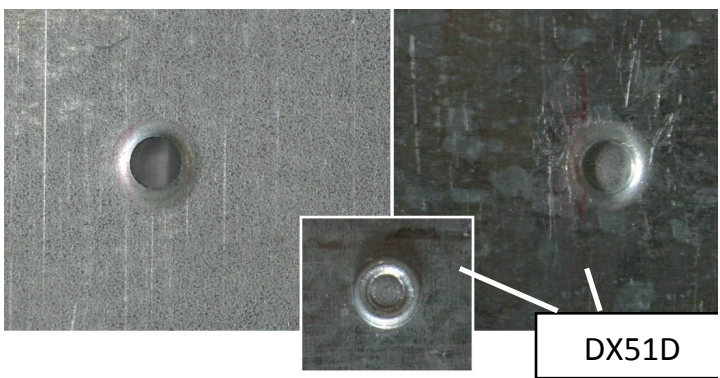

Fig. 5 Sample D without creating a clinched joint

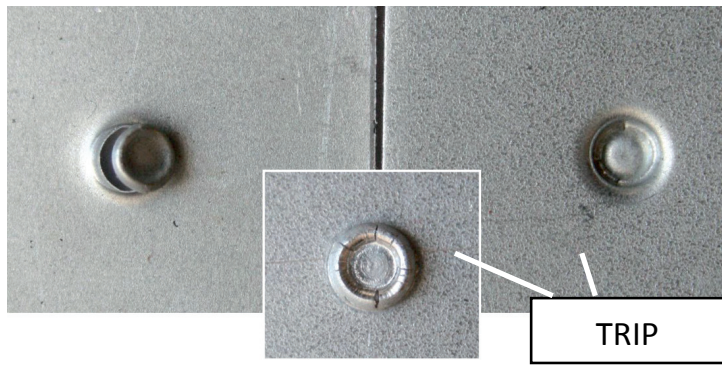

Fig. 6 Sample A after tensile test with cracks in the joint

The average value of carrying capacity of samples C was $970 \mathrm{~N}$. No cracks occurred in the place of the joint from the side of die (Fig. 7). The carrying capacity values of samples $\mathrm{C}$ are similar to the values measured in clinched joints of the common drawing grade steel sheets.

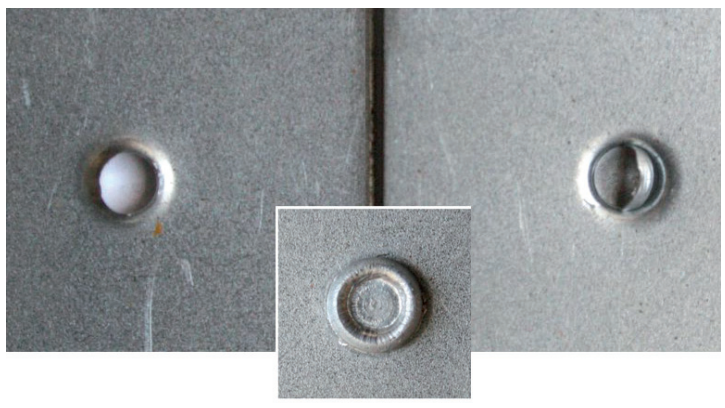

Fig. 7 Sample C after tensile test
The average value of carrying capacity of samples E was $1578 \mathrm{~N}$. The cracks in the TRIP steel of the die side were observed, similar to those in sample A (Fig. 8).

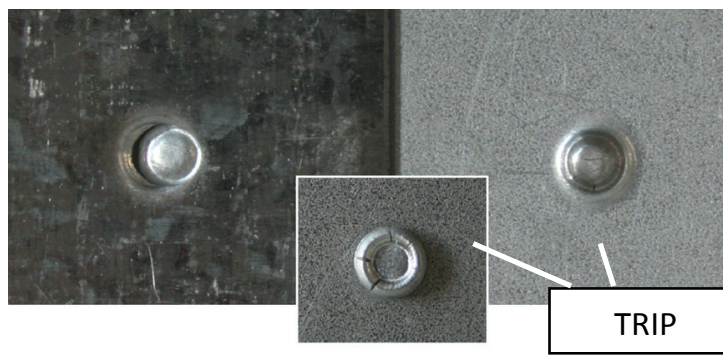

Fig. 8 Sample E after tensile test with cracks in the joint

The measured values of carrying capacity of samples $\mathrm{E}$ are higher than values of samples $\mathrm{A}$ and $\mathrm{C}$, which is probably caused by the thicker material of the upper sheet in the joint (DX51D of 0,9 $\mathrm{mm})$.

The results of metallographical analysis and the critical areas of clinched joints are shown in Fig. 9 - 11. Critical area is the area with the most significant thinning in the joint. Failures occured in these areas during tensile tests of samples $\mathrm{A}, \mathrm{C}$ and $\mathrm{D}$, and during the clinching process in samples $\mathrm{B}$ and D. The metallographical analysis confirmed the occurrence of cracks in the TRIP steel on the die side of the joints in the round part (Fig. 9).

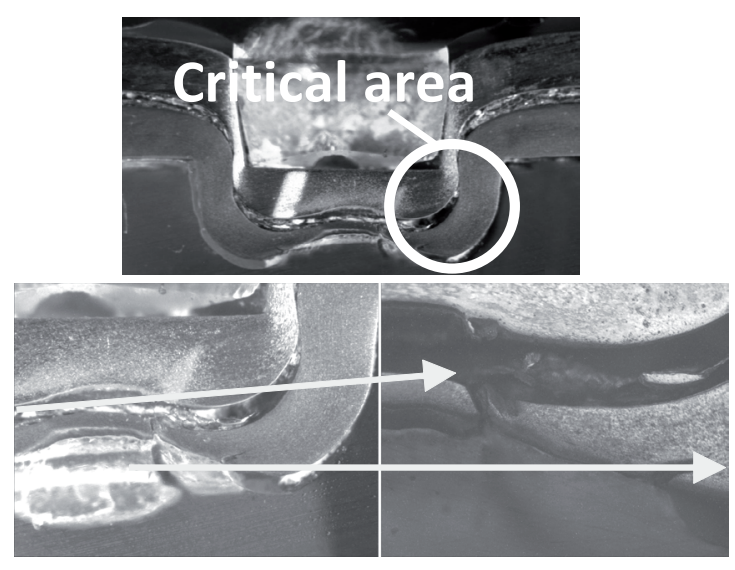

Fig. 9 Sample A with the critical area and the cracks in TRIP steel on the die side

Figure 10 shows sample $\mathrm{C}$ of two H220PD steels. There are no cracks or failures in the joint.

Figure 11 shows the critical area of the clinched joint of sample $\mathrm{E}$, which is different from the criti- 
cal area of sample C. It is caused by using the joint's upper sheet with a different thickness, which is in accordance with the values of carrying capacity measured during tensile test.

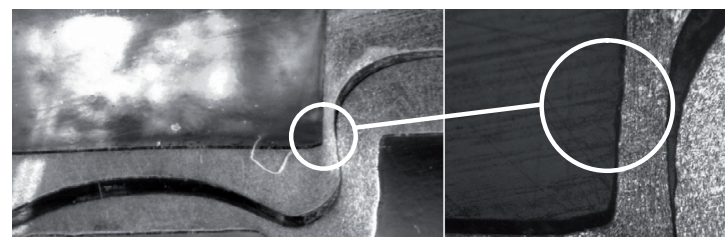

Fig. 10 Sample $C$ with the critical area of the joint

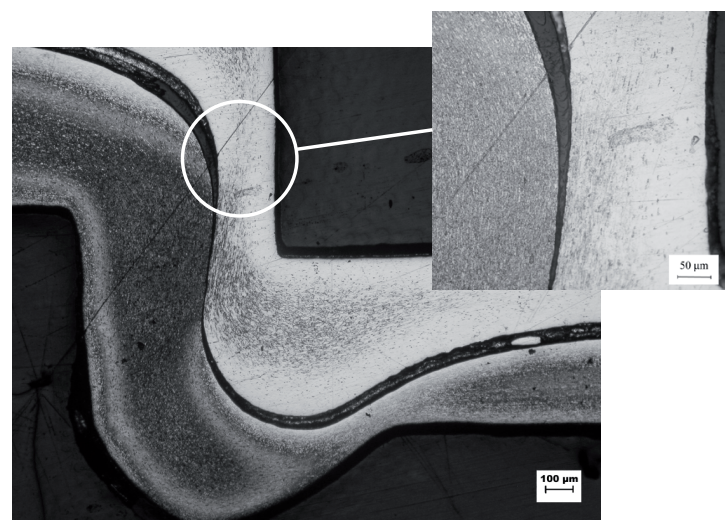

Fig. 11 Sample E with the critical area of the joint

\section{Conclusion}

The paper focused on the evaluation of clinched joints of various material combinations. Microalloyed steel HSLA H220PD, TRIP steel $40 / 70+\mathrm{Z} 100 \mathrm{MBO}$ and DX51D+Z steel were used for the experiments.

The influence of the orientation of joined materials regarding the position of punch and die of the tool was also observed. The material combinations of TRIP 40/70 with H220PD as well as TRIP 40/70 with DX51D, where TRIP steel is oriented towards the punch, are not suitable for joining by clinching, because the joints are not created. Failures in the critical areas of joints occur during the clinching process. The same material combinations, where TRIP steel is oriented towards the die, are not suitable for joining by clinching, even though the joints are successfully created, because there occur cracks in TRIP steel, which could negatively affect the joint, especially during dynamic load. The cracks can even decrease the corrosion resistance of the joints. Only the combination of the same materials H220PD is suitable for joining by clinching.
Carrying capacities of these samples were on sufficient level and metallographical analysis confirmed no occurrence of cracks or failures in the area of clinched joints.

\section{Acknowledgement}

This paper is the result of the project implementation: Center for research of control of technical, environmental and human risks for permanent development of production and products in mechanical engineering (ITMS:26220120060) supported by the Research \& Development Operational Programme funded by the ERDF.

\section{References}

[1] Han L., Thornton M., Shergold M., A comparison of the mechanical behaviour of selfpiercing riveted and resistance spot welded aluminium sheets for the automotive industry, Materials and Design, 31, 2010, p. 1457-1467

[2] Kašcák L., Spišák E., Tlakové spájanie ocel’ových plechov pre automobilový priemysel, PROTECH-MA 2005, Progressive Technologies and Materials, Rzeszów - Bezmiechowa 2005, p. 76 $-81$

[3] Spišák E., Kaščák L., Spájanie ocelových plechov $\checkmark$ automobilovom priemysle, In: MAT/TECH automobilového priemyslu, 2005, p. 97 - 102

[4] Kaščák L., Nové metódy tlakového spájania materiálov, Transfer inovácií, 8/2005, p. 99-100

[5] Varis J.P., Lepistö J., A simple testing-based procedure and simulation of the clinching process using finite element analysis for establishing clinching parameters, Thin-Walled Structures, 41, 2003, p. 691-709

[6] Oudjene M., Ben-Ayed L., On the parametrical study of clinch joining of metallic sheets using the Taguchi method, Engineering Structures, 30, 2008, p. 1782-1788

[7] Mucha J., The influence of shape of tool die and blankholder on effect of deformation joint elements and rivetion load values, In: Acta Mechanica Slovaca, 3-A/2008, p. 279-286

[8] Shiming G., Lothar B., Mechanism of mechanical press joining. Journal of Mechanical Tools Manufacturer, 34, 1993, p. 641-657

[9] Varis J.P., Ensuring the integrity in clinching process. Journal of Materials Processing Technology, 174, 2006, p. 275-277

[10] Kaščák L., Spišák E., Joints of thin sheets made 
by forming and resistance spot welding: evaluations of properties, IDDRG 2007 - Forming the future, Györ, Mad'arsko, p. 545-550

[11] Kaščák L., Spišák E., Evaluations of properties of clinching and resistance spot welding, In: Scientific Bulletins of Rzeszów University of Technology : Mechanics 73, no. 253, 2008, p. 161-166

[12] Spišák E., Kaščák L., Únosnost’ spájaných pozinkovaných ocelových plechov Zinkohal 350, In: Acta Mechanica Slovaca, 2-B/2006 - Protechma, p. 393-398

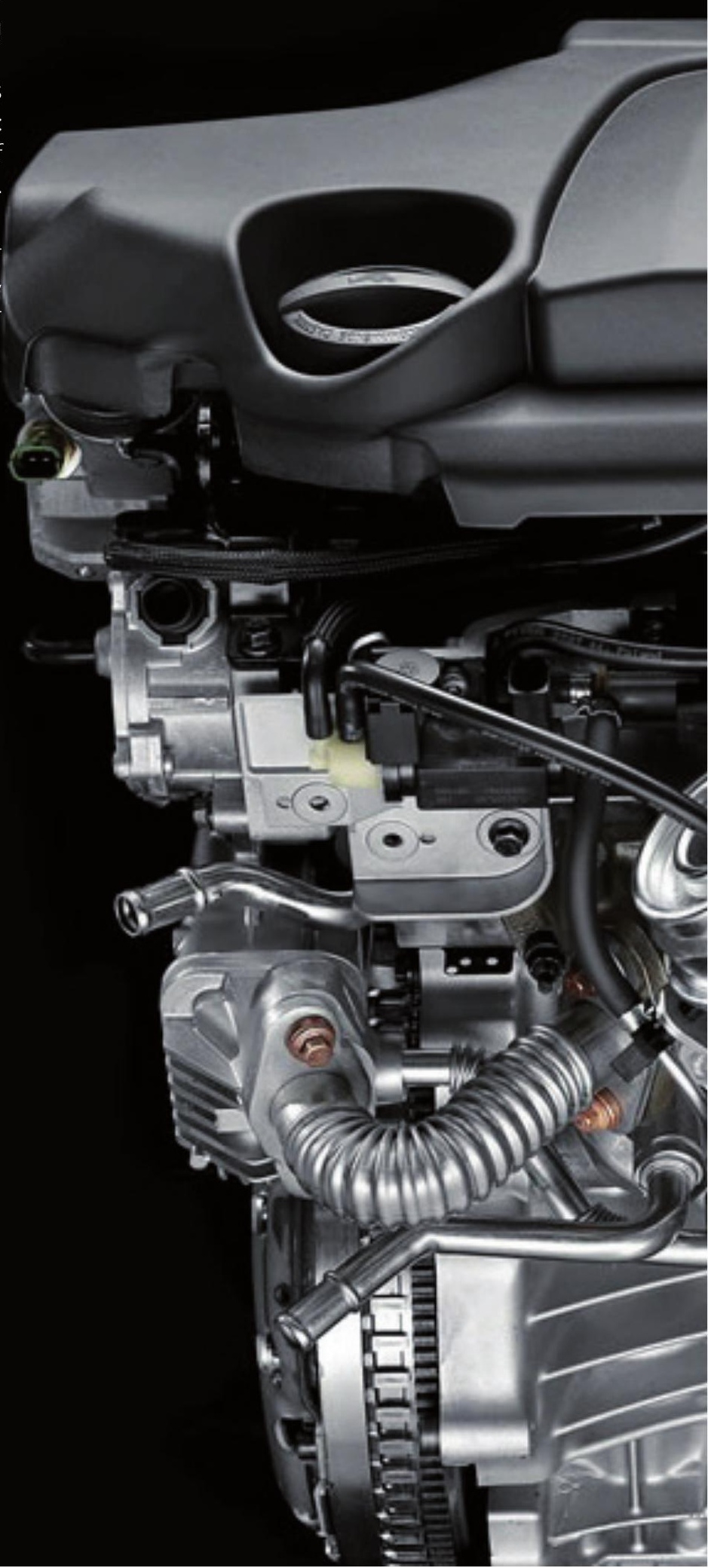



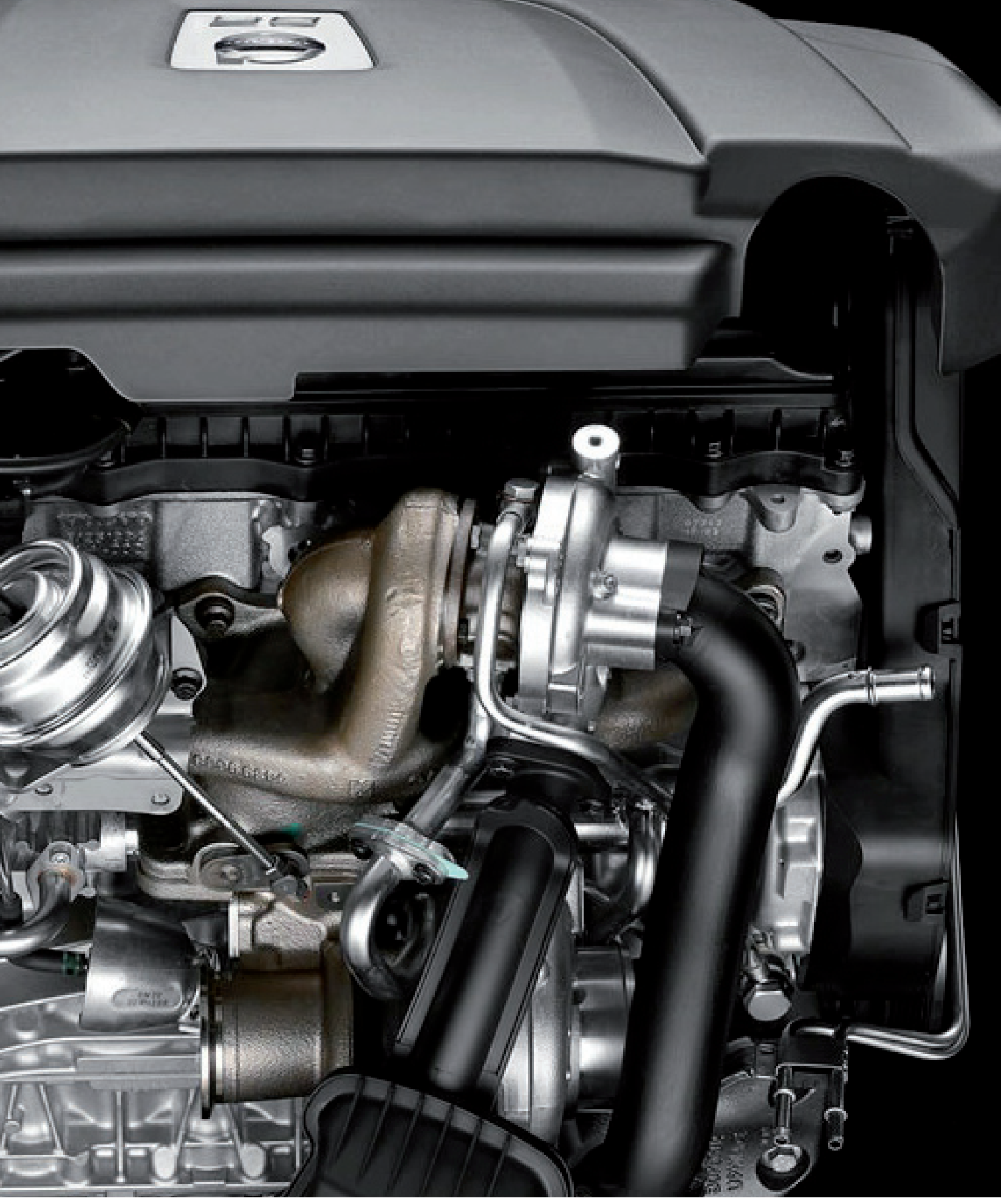